\title{
RECEIVED
}

\author{
JAN 261996
}

OSII

\section{The Effect of Dilution on the \\ Gas Retention Behavior of \\ Tank 241-SY-103 Waste}

P. R. Bredt

S. M. Tingey

January 1996

Prepared for

the U.S. Department of Energy

under Contract DE-AC06-76RLO 1830

Pacific Northwest National Laboratory

Operated for the U.S. Department of Energy

by Battelle Memorial Institute 


\section{DISCLAIMER}

This report was prepared as an account of work sponsored by an agency of the United States Government. Neither the United States Government nor any agency thereof, nor Battelle Memorial Institute, nor any of their employees, makes any warranty, express or implied, or assumes any legal liability or responsibility for the accuracy. completeness, or usefulness of any information, apparatus. product, or process disclosed, or represents that its use would not infringe privately owned rights. Reference herein to any specific commercial product, process, or service by trade name, trademark, manufacturer, or otherwise does not necessarily constitute or imply its endorsement, recommendation, or favoring by the United States Government or any agency thereof, or Battelle Memorial Institute. The views and opinions of authors expressed herein do not necessarily state or reflect those of the United States Government or any agency thereof.

\section{PACIFIC NORTHWEST NATIONAI, LABORATORY operated by \\ BATTELLE \\ for the \\ UNITED STATES DEPARTMENT OF ENERGY under Contract DE-AC06-76RLO 1830}

Printed in the United States of America

Avalable to DOE and DOE contractors from the Office of Scientific and Technical Information, P.O. Box 62, Oak Ridge, TiN 37831:

prices arailable from (615) 576-8401.

Available to the public from the National Technical Information Service, U.S. Department of Commerce, $\mathbf{5 2 8 5}$ Port Royal Rd., Springfield, VA 22161

This document was printed on recycled paper. 


\title{
The Effect of Dilution on the Gas Retention Behavior of Tank 241-SY-103 Waste
}

\author{
P. R. Bredt \\ S. M. Tingey
}

January 1996

Prepared for

the U.S. Department of Energy

under Contract DE-AC06-76RLO 1830

Pacific Northwest National Laboratory

Richland, Washington 99352 


\section{DISCLAMMER}

Portions of this document may be illegible in electronic image products. Images are produced from the best available original document. 


\section{Executive Summary}

The effect of dilution on gas retention in waste from Tank 241-SY-103 was investigated. A composite sample was prepared from material collected during the Core 62 sampling event. The composite contained material from both the convective and nonconvective layers in the proportions existing in the tank. The composite was diluted with $2 \mathrm{M} \mathrm{NaOH}$ at ratios of $0.50: 1,0.75: 1,1.0: 1$, and 3.0:1 by volume ( $2 \mathrm{M} \mathrm{NaOH}$ :tank waste). Although tank waste will have to be diluted with a mixer pump, the composite and diluted samples were only hand stirred to minimize any shear-induced decrease in shear strength.

The diluted samples and the composite were allowed to settle in duplicate for 20 days while the volume of settled solids was monitored. The volume-percent settled solids stabilized by the tenth day of settling for all dilutions.

The diluted samples and the composite were exposed to a $500-\mathrm{Ci}{ }^{137} \mathrm{Cs}$ source for 34 days while the volumes of settled solids, total waste, and gas in the head space were monitored. During the first three days of irradiation, additional settling was observed in the $0: 1$ and 0.50:1 diluted samples.

Delayed settling obscured the measurement of gas retention in the settled solids over the 34-day irradiation period. However, inspection of the sample vessels following the irradiation period revealed round gas bubbles retained by both the cohesive forces of the solids and by attachment to the solid particles. Following an initial delay of approximately $600 \mathrm{~h}$, gas-generation rates were seen to decrease with increasing dilution level, $0: 1>0.75: 1>1.0: 1$.

After 34 days of irradiation, a vacuum was applied to the head space of the sample vessels. The drop in pressure caused retained bubbles to expand and may also have caused other gases in solution to be drawn into bubbles. The composite and 0.50:1 diluted samples experienced gas retention and release events similar to an actual tank rollover. The 0.75:1, 1.0:1, and 3.0:1 samples did not exhibit rollover behavior. These results suggest that a $0.75: 1$ dilution of Tank 241-SY-103 waste will mitigate hazardous-gas-release-event behavior. 


\section{Acknowledgments}

This work was supported by the Tank Waste Safety Hydrogen Mitigation Program.

The authors wish to thank members of the Tank Waste Safety Flammable Gas Program, specifically P. A. Gauglitz and S. D. Rassat, for use of their in-cell video equipment. This equipment provided valuable data that could not have been collected with the existing systems. 


\section{Contents}

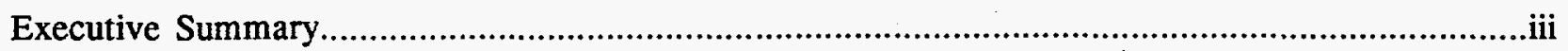

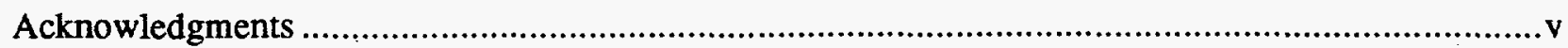

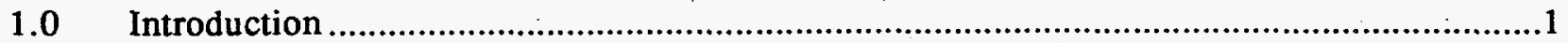

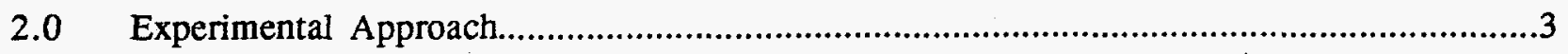

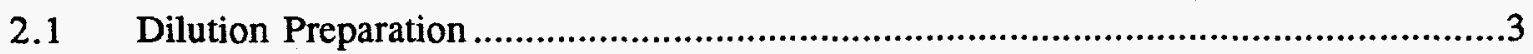

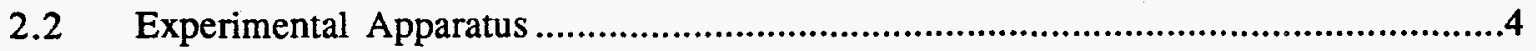

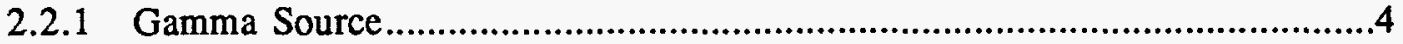

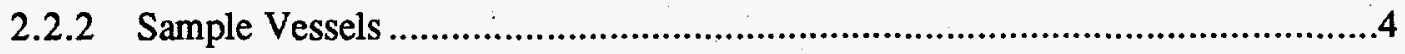

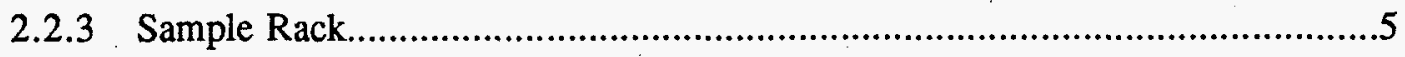

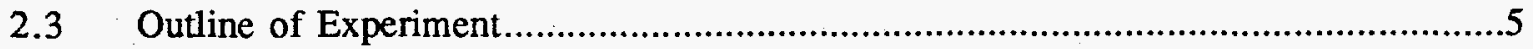

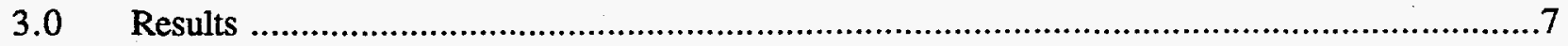

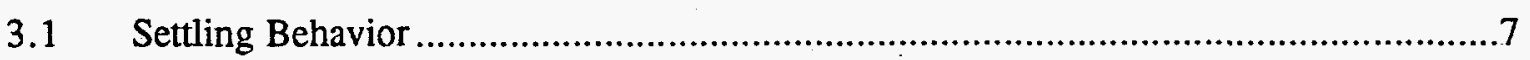

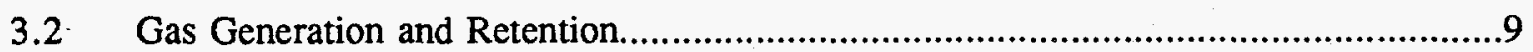

3.3 Applying Vacuum to the Sample Vessels...........................................................11

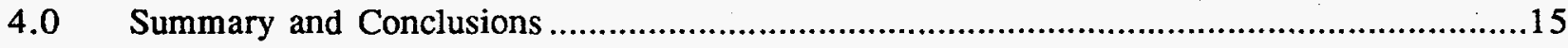

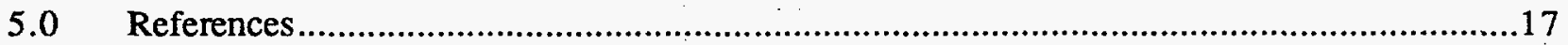

\section{Tables}

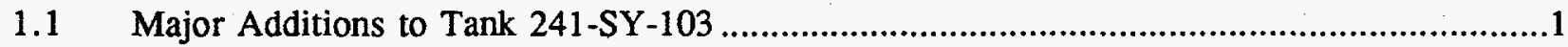

2.1 Composition of Nonconvective Composite Homogenized at 222-S..........................................

2.2 Core 62 Material Used to Prepare Tank Composite..............................................................4

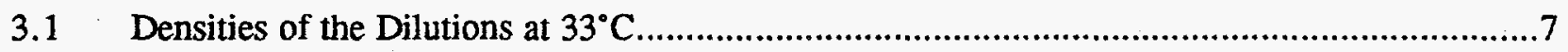

\section{Figures}

3.1 Volume Percent Settled Solids During the Settling and Irradiation Period...............................8

3.2 Gas Generation Plotted as Volume Change in the Head Space of the Sample Vessels ...........10

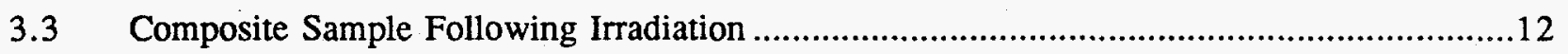

3.4 Duplicate Composite Sample Following Irradiation.................................................................13 


\subsection{Introduction}

Twenty-five of the 177 underground waste storage tanks on the Hanford Site have been placed on the Flammable Gas watch list. These 25 tanks, containing high-level waste generated during plutonium and uranium processing, have been identified as potentially capable of accumulating flammable gases above the lower flammability limit (Babad et al. 1991). In the case of Tanks 241-SY-101 and 241-SY-103, it has been proposed that diluting the tank waste may mitigate this hazard (Hudson et al. 1995; Stewart et al. 1994). The effect of dilution on the ability of waste from Tank 241-SY-103 to accumulate gas was studied at Pacific Northwest National Laboratory ${ }^{(2)}$. A similar study has been completed for waste from Tank 241-SY-101 (Bredt et al. 1995).

Because of the additional waste-storage volume available in Tank 241-SY-103 and because the waste is assumed to be similar to that currently in Tank 241-SY-101, Tank 241-SY-103 became the target for a demonstration of passive mitigation through in-tank dilution. In 1994, plans for the in-tank dilution demonstration were deferred pending a decision on whether to pursue dilution as a mitigation strategy. However, because Tank 241-SY-103 is an early retrieval target, determination of how waste properties vary with dilution will still be required.

Tank 241-SY-103 contains approximately $2.8 \mathrm{M} \mathrm{L}$ of waste with a height of $691 \mathrm{~cm}(272 \mathrm{in}$.) (Hanlon 1995). The tank received its first waste in 1977. A heel of complex concentrate (466,000 L) remained after transfers in and out of the tank between 1977 and 1980 . In $1980,1.6 \mathrm{M} \mathrm{L}$ of double-shell slurry were added on top of the heel. The last major addition was the transfer of $500,000 \mathrm{~L}$ of interstitial liquid and water from Tank $241-\mathrm{SX}-104$ in 1988 . With the exception of the 241-SX-104 liquid addition, the Tank 241-SY-103 fill history is chemically similar to Tank 241-SY101. Fox et al. (1993) list minor additions between $6 / 18 / 85$ and $5 / 31 / 93$, including uranium sludge and other smaller waste streams (see Table 1.1).

Table 1.1. Major Additions to Tank 241-SY-103

\begin{tabular}{|c|c|c|c|}
\hline Date & Volume (liters $\times 1000$ ) & Material & Comments \\
\hline 3rd quarter 1980 & 466 & Complex Concentrate & Residual Heel \\
\hline 4th quarter 1980 & 1600 & Double-Shell Slurry & $\begin{array}{l}\text { Entire } 2,057,000 \mathrm{~L} \\
(543,000 \text { gal }) \\
\text { Classified as Double- } \\
\text { Shell Slurry }\end{array}$ \\
\hline $6 / 85-11 / 85$ & 122 & $\begin{array}{l}\text { Solution of Sodium } \\
\text { Nitrate, Sodium } \\
\text { Hydroxide, and } \\
\text { Uranium }\end{array}$ & $\begin{array}{l}\text { Uranium sludge from } \\
\text { ion exchange process }\end{array}$ \\
\hline $7 / 1 / 88-8 / 13 / 88$ & 500 & $\begin{array}{l}\text { Interstitial Liquid and } \\
\text { Water from Tank 104- } \\
\text { SX }\end{array}$ & - \\
\hline
\end{tabular}

(a) Pacific Northwest National Laboratory is operated for the U.S. Department of Energy by Battelle under Contract DE-AC06-76RLO 1830. 
In August of 1994, samples were taken from Tank 241-SY-103. This sampling event, referred to as Core 62 , contained 15 segments. A segment is $48.26 \mathrm{~cm}$ (19 in.) in height. Initial results of the sample analysis indicate a stratification of waste in the tank with a total height of $686 \mathrm{~cm}$ (Hansen et al. 1995). The nonconvective layer extends from the bottom of the tank to a height of approximately $333 \mathrm{~cm}$. The convective layer extends from $333 \mathrm{~cm}$ to $673 \mathrm{~cm}$, and the crust, located on top of the convective layer, is no more than $13 \mathrm{~cm}$ thick. This stratification is similar to the conditions that existed in Tank 241-SY-101 before mixer-pump operations. In the Core 62 sampling, the nonconvective layer was contained in segments 10 through 14 , and the convective layer in segments 1 through 9 . The crust was not sampled. Segment 15 was found to contain primarily hydrostatic fluid, a $0.3 \mathrm{M} \mathrm{LiBr}$ solution used in the sampling process to prevent waste from traveling up the drill string; therefore, it was not a valid sample and was not used in any testing (Wilkins 1995).

Gas is generated in the waste as a result of both chemical and radiochemical decomposition. In-tank tests described by Stewart et al. (1995) have shown that gases are retained predominantly in the nonconvective layer. In addition, gases may be attached to the solid particles (Gauglitz et al. 1995 ) in a gas-slurry mixture that is held together by cohesive forces. When the buoyancy of the mixture is great enough to overcome the cohesive forces, the mixture rises to the surface and releases the retained gas. This rising of the gas-slurry mixture is referred to as a "rollover" or "gas release event"(GRE) (Allemann et al. 1993).

Even though diluting the tank waste has been considered a potential mitigation strategy for some time, direct experimental evidence to indicate the degree of dilution necessary to achieve mitigation has been lacking (Babad et al. 1992; Stewart et al. 1994). However, the effects of dilution on several related properties, including viscosity, shear strength, solids content and density, have recently become available for both Tank 241-SY-101 (Tingey et al. 1994) and Tank 241-SY-103( ${ }^{(4)}$. These results show a significant decrease in properties related to gas retention up to dilution ratios of 3.0:1 (diluent:waste) using $2 \mathrm{M} \mathrm{NaOH}, 0.01 \mathrm{M} \mathrm{NaOH}$ and deionized water.

Although no studies involving Tank 241-SY-103 waste have directly examined gas retention as a function of dilution, it is assumed that as the properties affecting gas retention decrease, mitigation could be achieved in one of three ways: 1) as the shear strength and viscosity of the material is decreased, the gas bubbles would no longer be retained in the nonconvective layer, and the gas would be released through the solids, 2) the density of the solids drops to a point at which neutral buoyancy is reached at low gas content, 3) the solids content drops, resulting in a lower absolute volume of retained gas. In the first case, rollover behavior is eliminated. In the last two, rollovers would still occur, however, the resulting gas concentrations in the tank head space would be below the lower flammability limit. Gas retention testing on Tank 241-SY-101 waste showed that by a dilution ratio of 1.0:1 with $2 \mathrm{M} \mathrm{NaOH}$, the first of these mitigation models was achieved. Gas bubbles were no longer retained in the sludge.

The scope of this study was to experimentally determine the effects of dilution on gas retention of actual waste samples. A tank composite was prepared from Tank 241-SY-103 material collected during the Core 62 sampling event. Dilutions were prepared using $2 \mathrm{M} \mathrm{NaOH}$ at ratios of $0.50: 1,0.75: 1,1.0: 1$, and 3.0:1 (diluent:waste). A $500-\mathrm{Ci}^{137} \mathrm{CsCl}$ source was used to generate gas in the dilutions while the settled solids volume and total waste volumes were monitored for the duration of this experiment.

(a) P.B. Bredt, J.D. Hudson, and J.M. Tingey. 1995. Effects of Dilution on the Physical, Rheological and Chemical Properties of Tank 241-SY-103 Waste. Letter Report to Westinghouse Hanford Company, MIT 092995, Pacific Northwest Laboratory, Richland, Washington. 


\subsection{Experimental Approach}

This section summarizes the apparatus used to assess changes in the gas-retention behavior of diluted waste samples as well as documenting the history of these samples. This work was conducted at the 325 building in the High Level Radiochemistry Facility (325A HLRF).

The goal of this work was to generate a measurable volume of gas in the waste and observe if this gas is retained in the settled slurry or lost to the head space. Two potential mechanisms for generating gas in the waste are thermal decomposition and radiolysis. Since properties related to gas retention are affected by temperature (Tingey et al. 1994), gas was generated by radiolysis. The experiment was conducted at ambient cell temperature, $33^{\circ} \mathrm{C}$, which is similar to actual tank conditions between $32^{\circ} \mathrm{C}$ and $38^{\circ} \mathrm{C}$ in the nonconvective layer (Wilkins, 1995).

\subsection{Dilution Preparation}

Seven samples from core 62 were received at the Pacific Northwest National Laboratory's 325A HLRF for gas-retention testing. These samples included one nonconvective-layer composite, one supernate composite, and five undisturbed samples, one from each segment collected from the nonconvective layer. The nonconvective layer composite was prepared at Westinghouse Hanford Company's 222-S laboratory in the 200 West area. Hand mixing was used to homogenize the composite sample. The ratio of segments used to make the composite is listed in Table 2.1. The supernate composite was prepared at $222-S$ using equal volumes of liquid from each of the convective-layer segments. The undisturbed samples were extruded from the samplers and placed in $125-\mathrm{mL}$ jars without any homogenization.

Table 2.1. Composition of Nonconvective Composite Homogenized at 222-S

\begin{tabular}{cr} 
Segment & Percent (by \\
\cline { 2 - 2 } 10 & 18.3 \\
11 & 24.6 \\
12 & 16.7 \\
13 & 24.0 \\
14 & 16.4
\end{tabular}

The subsamples of the convective and nonconvective composites prepared at 222-S were used for physical-properties testing. These subsamples were not returned to the bulk sample jar for use in gas-retention testing. The densities of the composites were measured in duplicate upon receipt. The supernate composite density was determined by placing samples in a preweighed graduated cylinder. The density was calculated by dividing the sample mass by the sample volume. Both duplicate samples had densities of $1.44 \mathrm{~g} / \mathrm{mL}$. The nonconvective composite density was determined by placing samples in preweighed graduated centrifuge cones. Samples were centrifuged for $2 \mathrm{~h}$ at $1000 \times$ g-forces to remove voids. Both duplicates had measured densities of $1.57 \mathrm{~g} / \mathrm{mL}$. The undisturbed segment samples were analyzed for shear strength, shear stress as a function of shear rate, and weight percent centrifuged solids.

A tank composite was prepared for gas-retention testing using the convective composite, the remaining material from the undisturbed segments, now disturbed, and the material from the 222-S prepared nonconvective composite. Table 2.2 lists the masses of material used. The tank composite was hand stirred to combine the material. 
Table 2.2. Core 62 Material Used to Prepare Tank Composite

\begin{tabular}{lr} 
Sample & Mass (g) \\
\cline { 3 - 3 } Segment 10 & 18.43 \\
Segment 11 & 15.32 \\
Segment 12 & 15.36 \\
Segment 13 & 9.16 \\
Segment 14 & 48.41 \\
Nonconvective Composite & 157.40 \\
Convective Composite & 295.69
\end{tabular}

Sample dilutions were prepared by adding ratios of $0.50: 1,0.75: 1,1.0: 1$, and $3.0: 1$ of $2 \mathrm{M} \mathrm{NaOH}$ (by volume) to the composite. For example, the $0.50: 1$ dilution was prepared with a known volume of waste (Y mL) and adding an additional $50 \%$ of that volume in $2 \mathrm{M} \mathrm{NaOH}(0.5 \mathrm{Y}$. $\mathrm{mL}$ ). The diluted waste was then slowly stirred with a spatula. The samples were left in the hot cell at approximately $33^{\circ} \mathrm{C}$ for a period of 10 days. Every other day, the samples were inverted to mix the solids and liquids.

\subsection{Experimental Apparatus}

\subsubsection{Gamma Source}

A single NORDION capsule (manufactured by NORDION International, Inc.) was used as the ionizing radiation source for the experiment. This capsule is a singly encapsulated $\{.94 \mathrm{~mm}(0.037$ in.) thick wall ${ }^{137} \mathrm{CsCl}$ source, $25 \mathrm{~cm}(9.84 \mathrm{in}$.) long and $.97 \mathrm{~cm}(0.38 \mathrm{in}$.) in diameter with an activity of approximately $500 \mathrm{Ci}$ (gamma energy $0.66 \mathrm{MeV}$ ) at the time of this work. To meet 325 Building Safety Analysis Report requirements, a secondary .32 -cm-thick (.125 in.) steel capsule was added to the primary encapsulation. A third jacket approximately $.159 \mathrm{~cm}$ thick $(.0625 \mathrm{in}$.) was used to prevent contamination of the source while in the HLRF.

Dose rates were measured 10.16 and $20.32 \mathrm{~cm} \mathrm{(4} \mathrm{and} 8$ in.) from the triply encapsulated source using thermoluminescent detectors (TLDs). Twenty-five TLDs were exposed to the source for $1 \mathrm{~h}$ using the sample holder described in Section 2.2.3. The TLDs were read by PNNL Health Physics. The TLDs were divided into sets of five. Each set was placed into one of five 125 -mL glass jars. Four of the TLD sets were exposed at four different loactions, $20.32 \mathrm{~cm}(8 \mathrm{in}$.) from the source. The error within each set was $\pm 5 \%$. Using the data from all four sets, the dose rate was determined to be $2.7( \pm 0.2) \mathrm{kR} / \mathrm{h}$. The variability between locations is larger than the error in TLD readings within the sets. This variability is most likely the result of errors in centering the jars in the sample-holder locations. At $20.32 \mathrm{~cm}(8 \mathrm{in}$.) from the source, a $0.64 \mathrm{~cm}(0.25 \mathrm{in}$.) error in centering the TLDs would have resulted in a 7\% change in the measured dose rate. This error in placement of the TLD jars should not have occurred with the actual waste samples since the vessels used with the samples were machined to fit into the sample holder to $0.03 \mathrm{~cm}( \pm 0.01$ in.). One TLD set was exposed at one location, $10.16 \mathrm{~cm}(4 \mathrm{in}$.) from the source. It measured a dose rate of $8.2 \mathrm{kR} / \mathrm{h}$. No variability associated with position can be assigned from the single location at $10.16 \mathrm{~cm}(4 \mathrm{in}$.); however, the

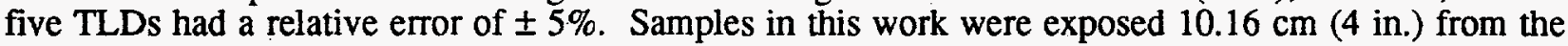
source.

\subsubsection{Sample Vessels}

During testing, the samples were contained within graduated plexiglass vessels. The vessel lids, sealed with two silicone gaskets, were made of plexiglass and equipped with a graduated quartz manometer containing mercury. The mercury served to retain water vapor and indicate any volume changes in the system during irradiation. Ten caps were fabricated without manometers and used during the settling phase of testing. The manometers were glued to the caps using silicone rubber 
cement. Five of the manometers were additionally secured to the caps with high vacuum resin. The five manometers without resin developed leaks during the irradiation phase of testing. The cap on one of the undiluted samples was equipped with a thermocouple extending into the settled-solids layer. This thermocouple was used to measure the temperature of the samples during irradiation. Photographs of the vessels and manometer assemblies are included in a previous gas-retention-testing report on Tank 241-SY-101 waste (Bredt et al. 1995). The Tank 241-SY-101 vessels included a heated water jacket not employed in this testing.

Materials were tested for radiation durability at the 300 Area gamma-pit facility in the 3730 building. Materials were inspected at total doses of $10^{6} \mathrm{R}, 10^{7} \mathrm{R}$, and $10^{8} \mathrm{R}$. All materials performed acceptably up to $10^{7} \mathrm{R}$. The plexiglass failed by $10^{8} \mathrm{R}$ total dose. No gas generation was detected during radiation testing of the plexiglass or silicone rubber cement.

\subsubsection{Sample Rack}

A round rack was fabricated to hold the sample vessels at a fixed distance from the source during irradiation. The stainless steel rack was equipped with a lazy Susan to aid in sample loading and inspection. The gamma source was held vertically in the center of the rack. The rack contained 20 sample positions, 10 at $20.32 \mathrm{~cm}(8 \mathrm{in}$.) from the source and 10 at $10.16 \mathrm{~cm}$ (4 in.) from the source. These distances are from the center of the source to the center of the sample. During this study, all samples were placed $10.16 \mathrm{~cm}(4 \mathrm{in}$.) from the source.

\subsection{Outline of Experiment}

The samples were diluted as described in Section 2.1. The samples were loaded into the vessels in duplicate and sealed and allowed to settle undisturbed for approximately 20 days at $33^{\circ} \mathrm{C}$ $\left( \pm 2^{\circ} \mathrm{C}\right)$. The gamma source was then placed in the center of the rack, and the mercury manometers were installed on the vessels. The temperature of the undiluted sample was monitored during irradiation at between $31.6^{\circ} \mathrm{C}$ and $34.9^{\circ} \mathrm{C}$. The volume of the settled solids, total waste (solids and liquids) and system (solids, liquids, and head space) were monitored for 34 days. Videotape recordings were made to document visual observations.

Following the irradiation phase of testing, the vessels were attached to the facility vacuum system and pumped down to a vacuum of approximately 22 in. of mercury. Application of a vacuum was not in the original scope of the work, so the facility vacuum gauge was not calibrated to meet PNL quality assurance Impact Level II requirements. Data from this gauge were used for indication only. Slurry growth and waste behavior were monitored and recorded with the video equipment both inside and outside the cell.

During the irradiation phase of the experiment, measurements were taken on a regular basis, including settled-solids volume, total-waste volume, displacement of the mercury in the manometers, absolute pressure in the hot cell gallery, the differential pressure between the hot cell and the gallery, the hot cell temperature, and the temperature in the settled solid layer of one of the undiluted samples.

Displacement of the mercury columns, absolute pressure in the gallery, and the cell differential pressure were used to calculate the pressure in the vessels. This was combined with the increase in head space volume, measured as the displacement of the mercury, to calculate the gas generation. Gas could be either in the head space or retained in the solids. No gas bubbles were observed in the liquid.

It is possible to determine the gas-retention mechanism using changes in the total waste volume and changes in the settled-slurry volume. Two types of bubbles (dendritic and round (Gauglitz et al. 1995) \} have been identified as retained in the settled layer of simulated waste. Dendritic bubbles fill the space between particles and displace the interstitial liquid. Dendritic bubble volume is measured as an increase in the total waste volume only. Round bubbles push the particles 
and liquid out of the way and increase the settled-slurry volume and total-waste volume equally; therefore, total gas retention is measured as the change in the total-waste volume. Round-bubble volume is determined by the change in settled-solids volume, and dendritic-bubble volume is calculated by subtracting the round-bubble volume from the total gas retention. Due to the minimal waste height, $\sim 10 \mathrm{~cm}$, and the scaling suggested by Gauglitz et al. (1995), it was expected that only round bubbles should form under these experimental conditions. 


\subsection{Results}

This section summarizes the effects of dilution on the gas-retention ability of Tank 241-SY103 waste. A whole tank composite was studied at dilution ratios of $0: 1$ (undiluted), $0.50: 1,0.75: 1$, 1.0:1, and 3.0:1 using $2 \mathrm{M} \mathrm{NaOH}$. Work was conducted at $33^{\circ} \mathrm{C}$. Properties discussed in this section include settling behavior, radiolytic gas generation rates, and gas retention behavior. The raw data are contained in laboratory notebook BNW-55817. The apparatus was designed to "Good Practices Standards." As per client request, work with actual tank waste was performed to Impact Level II requirements. Impact levels are described in operating manual PNL-MA-70.

\subsection{Settling Behavior}

A known mass of diluted sample was loaded into each of the nine plexiglass sample vessels. With the exception of the 3.0:1 diluted sample, all dilution levels were studied in duplicate. The 3.0:1 sample contained 7.7 volume percent settled solids. Due to concerns that this small amount of solids would be difficult to measure in the plexiglass vessels, $42 \%$ of the supernate was decanted from the sample, increasing the volume percent solids to $12.5 \%$. The resulting 3.0:1 material was loaded into only one vessel. The vessels were capped, and the total sample volume and volume of settled solids were measured throughout the course of the experiment. The waste density was calculated by dividing the mass of the waste by the total volume. The volume used in the density calculation was the average measured over the first three days of settling. The densities of the dilutions are listed in Table 3.1. The density listed in Table 3.1 for the $0: 1$ sample, $1.60 \mathrm{~g} / \mathrm{mL}$, is higher than the nonconvective composite, $1.57 \mathrm{~g} / \mathrm{mL}$. A foam was observed floating on the top of the liquid layer of both $0: 1$ samples during the first 2 weeks of settling. This foam, caused by the release of trapped gas, could explain the higher than expected density of the samples.

Table 3.1. Densities of the Dilutions at $33^{\circ} \mathrm{C}$

$\begin{array}{rr}\text { Dilution } & \text { Density }(\mathrm{g} \\ 0: 1 & 1.60 \\ 0.50: 1 & 1.40 \\ 0.75: 1 & 1.37 \\ 1.0: 1 & 1.34 \\ 3.0: 1 & 1.23\end{array}$

The volume-percent settled solids was calculated by dividing the settled-solids volume by the total waste volume. The volume-percent settled solids is plotted as a function of time in Figure 3.1. Volumes in the sample vessels were read to $\pm 0.5 \mathrm{~mL}$. All samples reached a stable settled-solids volume within the first 10 days. As Figure 3.1 shows, the volume-percent settled solids for the undiluted samples differed after 21 days of settling. The duplicate $0: 1$ samples had $68 \%$ and $91 \%$ settled solids respectively. Gas-retention properties are affected by shear history; therefore, none of 

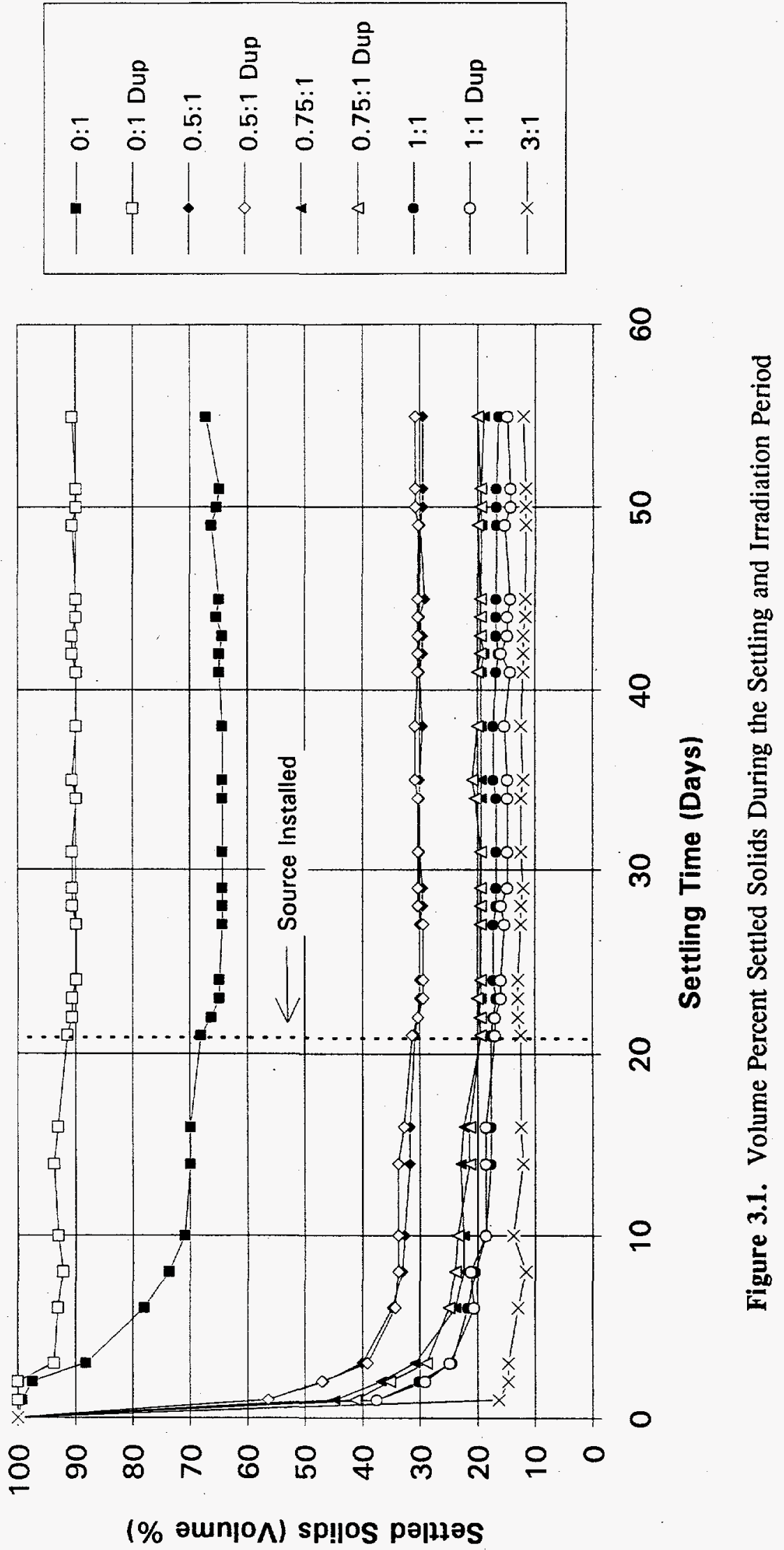
the samples were vigorously mixed before filling the sample vessels. As a result of not mixing, the duplicate 0:1 sample, which was filled second, received a larger amount of the settled solids.

However, the average settled solids, $80 \%$, compares well to the value of $79 \%$ for a tank composite prepared during earlier testing in our laboratory ${ }^{(\mathbf{z}}$.

The source was installed in the rack after 21 days of settling. By the end of day 24, the volume-percent settled solids dropped in all of the 0:1 and 0.50:1 samples. Gas-retention testing on Tank 241-SY-101 waste displayed similar behavior following installation of the source. In 241-SY101 testing, the drop was seen at all dilution levels and was accompanied by the formation of surface structures, including cracks, bulges, and craters at the solids-liquid interface. These structures were not observed in the 241-SY-103 samples; however, the changes in volume-percent solids in the 241SY-103 samples were only approximately $3 \%$ while the $241-$ SY-101 samples experienced drops of up to $20 \%$. Surface structures and settled-bed collapses have been observed in iron oxide suspensions (Glasrud et al. 1993). When the source was introduced, a small mechanical agitation may have occurred, disturbing a stable structure; however, agitating this waste form would normally be expected to loosen the fine solids, causing an initial increase in the volume-percent settled solids and a clouding of the liquid phase.

\subsection{Gas Generation and Retention}

As Figure 3.1 shows, the volume-percent settled solids did not measurably increase over the irradiation period, day 21 to day 55. However, inspection of the samples with an in-cell video camera showed the presence of round bubbles in all of the samples. As noted in Section 3.1, the solids experienced measurable settling at the start of the irradiation phase of the experiment. This settling must have continued throughout the irradiation phase and masked the slurry growth caused by bubble formation.

Total gas-generation data are plotted in Figure 3.2 as an increase in volume from $241 \mathrm{~h}$ after the start of irradiation. This volume change has been corrected to 760 torr. The data have not been corrected for temperature because temperature gradients within the head space were not measured ${ }^{(b)}$. Data before $241 \mathrm{~h}$ showed a net loss of approximately $0.6 \mathrm{~mL}$ of gas. This loss is most likely a result of oxygen and nitrogen consumption. Although a net gas loss is not seen after $241 \mathrm{~h}$, the consumption would be expected to have continued throughout the irradiation phase and contributed to a lower measured total gas generation.

Figure 3.2 shows similar gas-generation rates for the $0: 1,0.75: 1$, and $1.0: 1$ samples. Valid gas-generation data are not available for the $0.50: 1$ and $3.0: 1$ diluted samples due to leaks that developed at the base of the mercury manometers during the irradiation phase of testing. Decreases in sample volumes were not noted in the leaking or gas-tight vessels. Therefore, these leaks were not accompanied by evaporation, and the composition and gas-retention data are unaffected by the leaks.

Data for the last $200 \mathrm{~h}$ suggests that gas generation follows the order $0: 1>0.75: 1>1.0: 1$; however, this trend is not present from $241 \mathrm{~h}$ to $600 \mathrm{~h}$. It is possible that oxygen and nitrogen consumption during the earlier hours of irradiation is masking the trend.

(a) A sample of the Tank 241-SY-103 nonconvective composite was diluted 1.0:1 by volume with material from the convective composite in duplicate. The diluted samples were vigorously agitated and then allowed to settle for 3 days at $28^{\circ} \mathrm{C}$. The duplicate samples showed $78 \%$ and $79 \%$ settled solids by volume.

(b) The head space volume was approximately $47 \mathrm{~mL}$ exposed to an ambient temperature of approximately $29^{\circ} \mathrm{C}$ compared to a waste temperature of approximately $33^{\circ} \mathrm{C}$. Cell temperature and sample temperatures were observed to vary by approximately $\pm 2^{\circ} \mathrm{C}$ over the course of the experiment. 


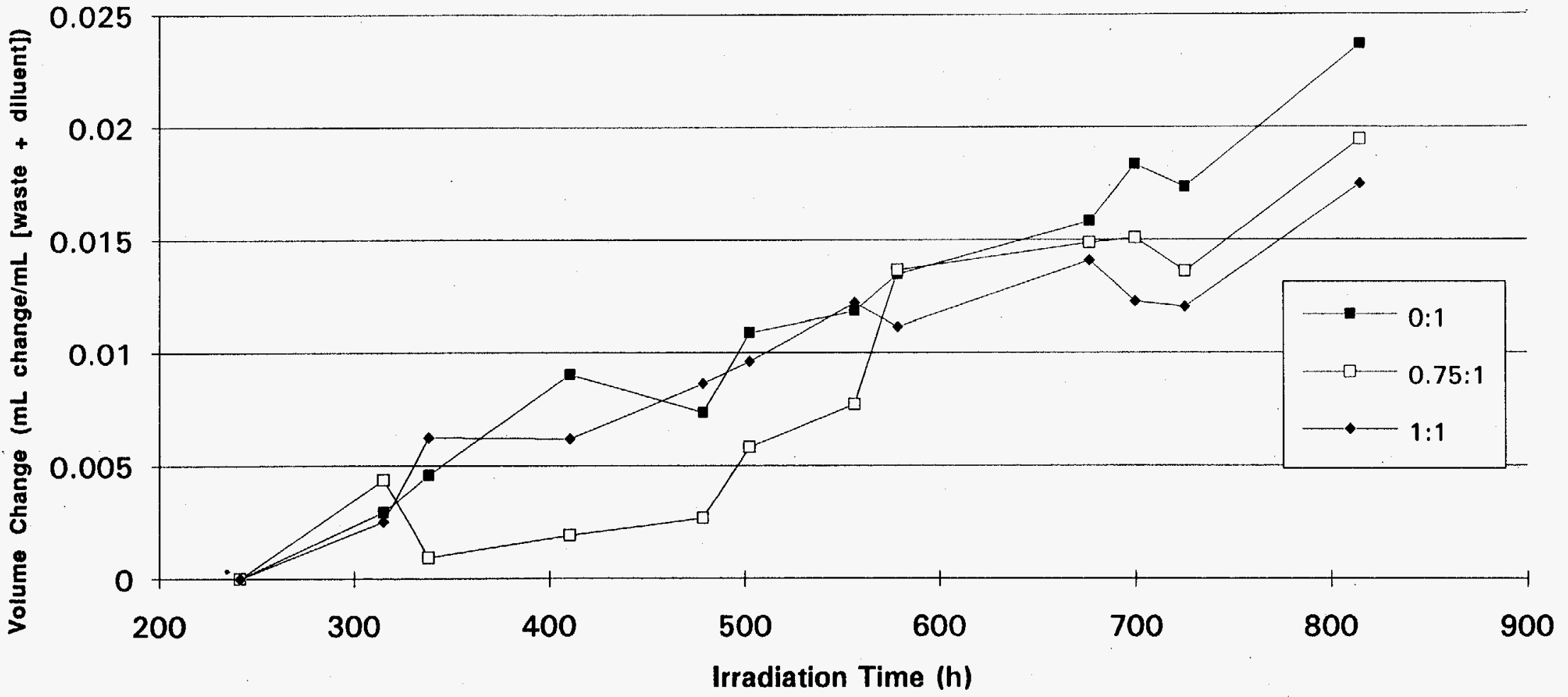

Figure 3.2. Gas Generation Plotted as Volume Change in the Head Space of the Sample Vessels. These data have not been corrected for temperature differences between the vessel and the manometer. 


\subsection{Applying Vacuum to the Sample Vessels}

After 34 days of irradiation at $8.2 \mathrm{kR} / \mathrm{h}\left(6.7 \times 10^{6} \mathrm{R}\right)$, no gas retention was observed. Several factors could have contributed to this observation: 1) Only $1.3 \mathrm{~mL}$ of gas were generated (in the 1.0:1 sample) during the irradiation period. Gas-retention testing on Tank $241-S Y-101$ waste at $50^{\circ} \mathrm{C}$ and $1.6 \times 10^{6} \mathrm{R}$ resulted in approximately $2 \mathrm{~mL}$ of generated gas. The volume generated in Tank 241-SY-103 testing was lower than anticipated and could have been exceeded by volume changes resulting from collapses in the settled bed. 2) Gas formed in the solids could have diffused out. The vessels were $2.54 \mathrm{~cm}$ in diameter, so gas diffusing through the solids would only need to travel 1.27 $\mathrm{cm}$ to the walls where cracks running up the sides of the settled bed could carry it to the liquid layer. However, the observation of bubbles in the settled-solids bed implies that diffusion was not the major cause; rather, the bed probably settled.

Two experimental conditions (shear history of the waste samples and small settled-bed heights) were anticipated to cause poor gas retention, but evacuation showed this not to be a problem. The shear strength of Tank 241-SY-103 nonconvective-layer waste is a factor contributing to gasretention behavior. Previous work with Tank 241-SY-101 waste showed a decrease in shear strength with increasing shear history (Tingey et al. 1994). Some samples used to prepare the Tank 241-SY103 composite had been exposed to shearing forces on the order of $500^{3-1}$ during rheological analyses. Most samples only experienced hand mixing, $>10^{s-1}$. It was anticipated that the shear history of the samples and the small bed height, resulting in less compaction of the settled-solids layer, would reduce the shear strength of the settled-solids layer such that gas bubbles would not be retained. However, the composite and the 0.50:1 diluted samples possessed sufficient shear strength to retain gas bubbles.

It was decided that a vacuum should be applied to the head space of all samples. In real waste studies and simulant studies (Bredt et al. 1995, Gauglitz and Rassat 1995) this technique has been shown effective in expanding existing bubbles and causing dissolved gases, primarily $\mathrm{NH}_{3}$ (Norton and Pederson 1994), to nucleate or further increase the size of existing bubbles.

The vacuum in this study was provided by the 325 building vacuum system. A vacuum gauge located in the 325A HLRF front gallery was used to estimate the vacuum at 22 in. of mercury. The rate at which the vacuum was applied to the head space was not accurately controlled. The vessels reached $22 \mathrm{in}$. of mercury within about 1 to $2 \mathrm{~min}$. The height of the settled solids increased in the composite, and the 0.50:1, 0.75:1, and 1.0:1 diluted samples indicated round-bubble growth. Bubble shape was confirmed by in-cell video. Bubbles were observed releasing from the solids at all dilution levels, including the 3.0:1 ratio, but no bubbles were observed nucleating in the liquid (supernate) layer.

When the vacuum was applied, the solids level in the two composite samples raised by $16 \%$ and $19 \%$. The sample that raised $19 \%$ remained at that level for approximately $1 \mathrm{~min}$ before the solid cohesion was lost, and the solid-gas mixture rose to the surface. The sample that raised $16 \%$ contained only a $10 \%$ by volume supernate. During slurry growth, most of this supernate was. observed to percolate into the sample, preventing the possibility of a rollover. The $0.50: 1$ diluted samples raised as the vacuum was applied. When the settled solids raised $13 \%$ in the first sample and 9\% in the second, the solid-gas mixture lost cohesion, and the solid-gas mixture sheared. A majority of the solid-gas mixture rose to the surface. The settled solids in the $0.75: 1$ samples raised by $8 \%$ and 9\%; however, 2-mm to 3-mm diameter bubbles were released from the solids one at time with very little disturbance to the settled-solids bed. Some minor clouding of the liquid layer was observed resulting from suspended fine particles. The settled solids in the $1.0: 1$ samples grew by $7 \%$ and $9 \%$, and as with the $0.75: 1$ dilution, bubbles up to $5 \mathrm{~mm}$ were observed escaping from the solids, one at a time, with very little disturbance to the settled-solids bed. No solids were observed to increase in height in the 3.0:1 diluted sample, but several small $0.5-\mathrm{mm}$ bubbles were observed escaping from the solids. 
Video images were collected to supplement observations during the evacuation phase of testing. Bubbles were round and approximately 0.2 to $0.5 \mathrm{~mm}$ in diameter before applying the vacuum (see Figure 3.3). In many cases, the bubbles were contained in irregularly shaped (not round) liquid-filled pockets. These bubbles are retained by the shear strength of the solids. Many liquid-filled pockets did not contain gas bubbles. This suggests that these bubbles grow within the pockets and push out the surrounding liquid; however, with no observations during the irradiation phase, a definite conclusion cannot be made. Many of the bubbles are surrounded by solids. Given the small size of most of the bubbles, it is difficult to determine the extent of attachment to solid particles. However, in several vessels, independent of dilution level, bubbles were observed attached to particles at the solid-liquid interface (top of the settled-solids bed). Two of these bubbles in a 0.75:1 sample remained attached to the solids until reaching approximately $3 \mathrm{~mm}$ in diameter. This shows that bubble attachment to the solids does contribute to retention of some bubbles. Application of the vacuum caused expansion and coalescence of the bubbles up to sizes of $5 \mathrm{~mm}$ in diameter.

Following rollovers, bubbles up to $7 \mathrm{~mm}$ were visible. Future work will focus on the mechanisms of bubble retention.

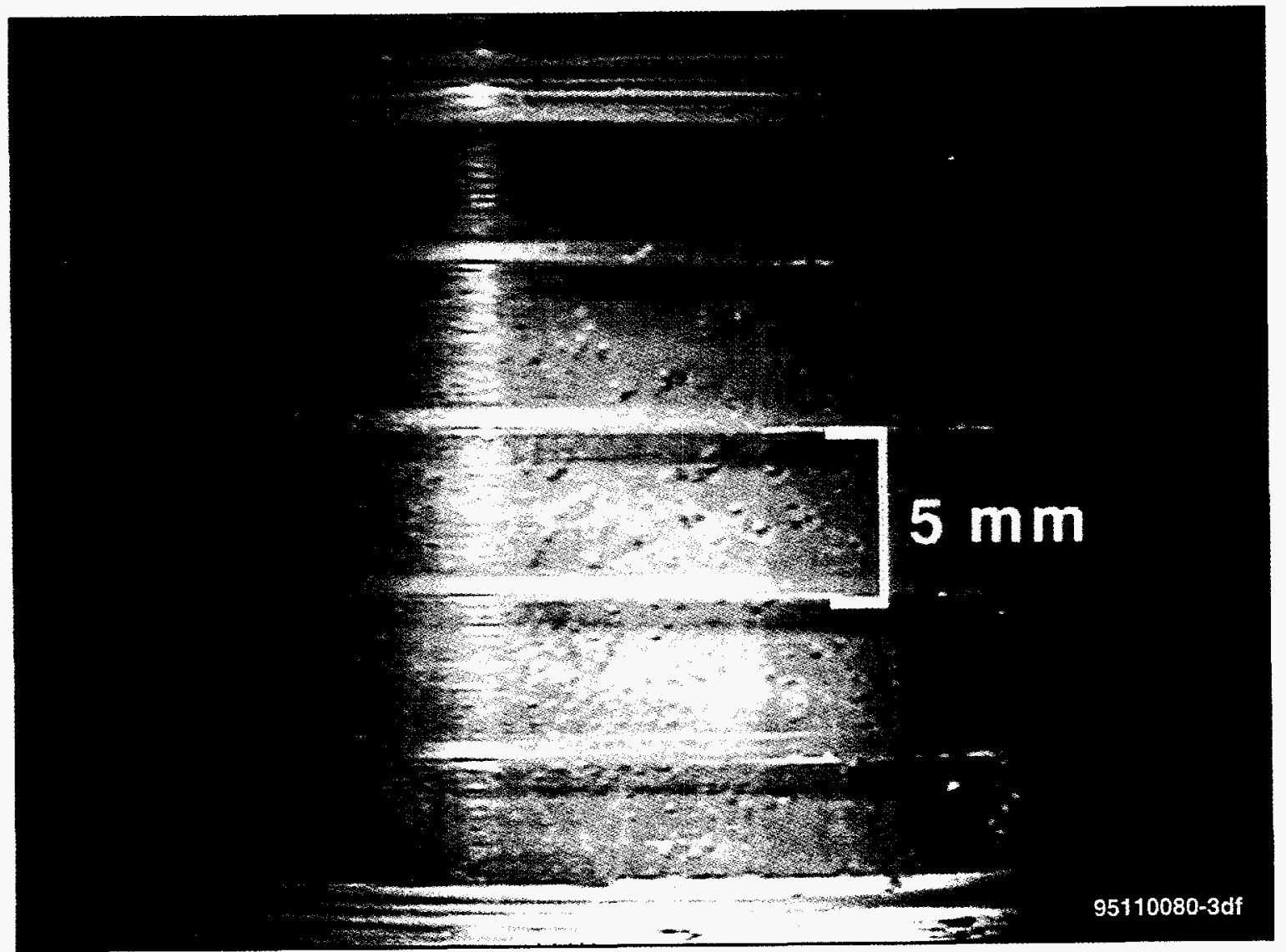

Figure 3.3. Composite Sample Following Irradiation 
The release events of the composite and 0.50:1 diluted samples followed behavior observed in actual tank rollovers: 1) large amounts of solids were involved in the release, 2) the rise occurred throughout the vessels at the same time, 3) the event was initiated by a yielding of the material, and 4) the events were short in duration. The releases in the $0.75: 1$ and 1.0:1 diluted samples were dominated by individual bubble releases and were slower with bubbles releasing over a longer time than the rollovers. The bubbles in the $0.75: 1$ and 1.0:1 samples had very little interaction with the solids and were released through the solids. This result indicates that at a dilution level below $0.75: 1$, bubbles are formed and retained by the solids, and at levels of $\geq 0.75: 1$, bubbles are not retained by the solids.

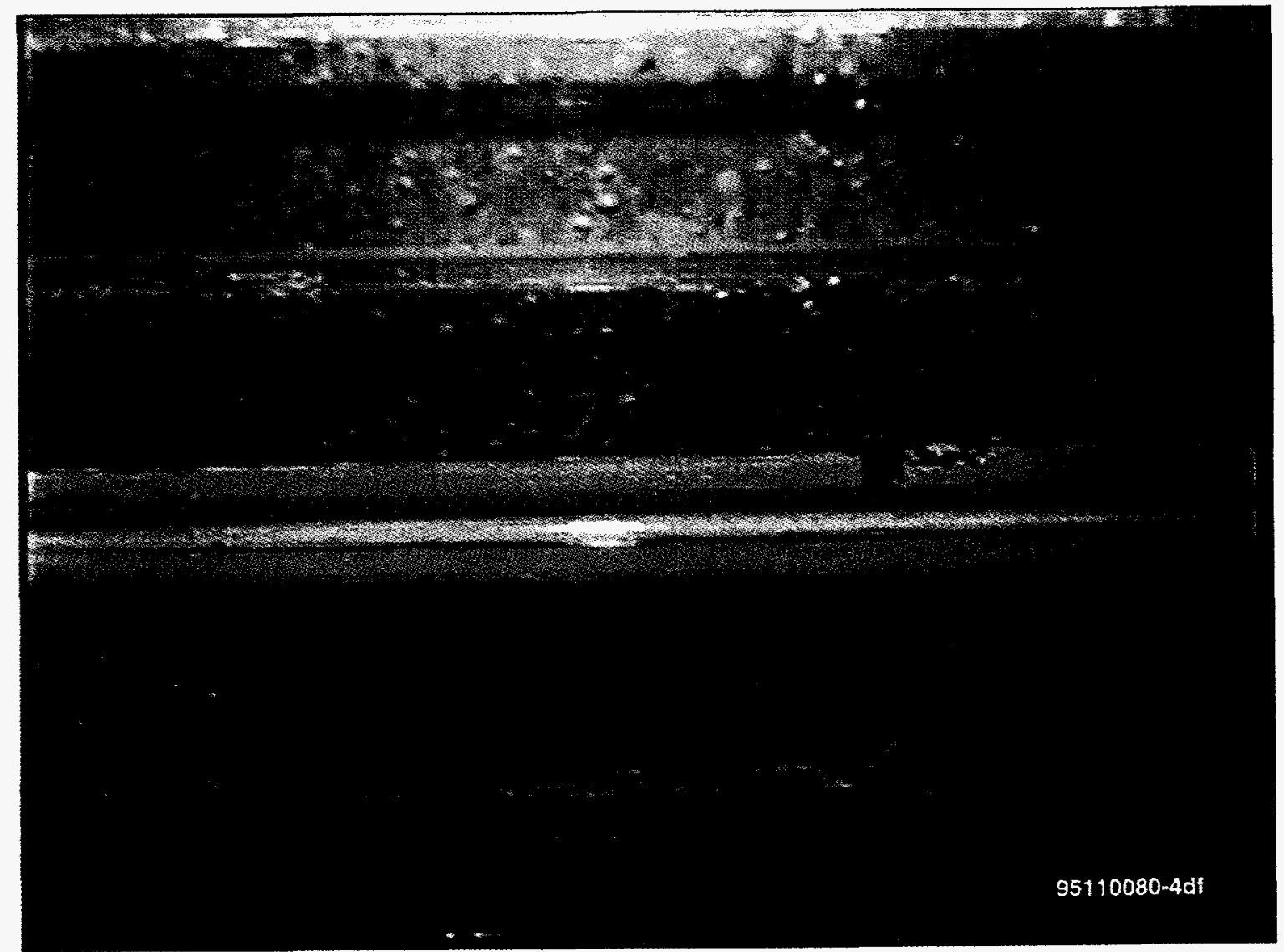

Figure 3.4. Duplicate Composite Sample Following Irradiation 



\subsection{Summary and Conclusions}

The effect of dilution on the ability of Tank 241-SY-103 waste to retain gas was investigated. Gas-generation rates were similar for the tank composite and 0.75:1 and 1.0:1 diluted samples. Following an initial delay of approximately $600 \mathrm{~h}$, gas-generation rates were seen to decrease with increasing dilution level, $0: 1>0.75: 1>1.0: 1$.

Settling of the solid beds during the irradiation obscured the measurement of slurry growth resulting from gas retention. Inspection of the samples following irradiation showed round bubbles present in the settled solids. These bubbles were retained by both the shear strength of the solids and by attachment to the solid particles. Further work is required to determine if other mechanisms are also responsible for gas retention.

Application of a vacuum to the head space of the vessels caused the settled solids to raise in all the samples except the 3.0:1 dilution ratio. The composite and 0.5:1 samples experienced gas retention and events similar to tank rollovers. The 0.75:1 and 1.0:1 samples released gas through the solids over an extended period without significantly disturbing the settled solids layer. Fewer gas bubbles were observed releasing from the 3.0:1 sample, and no increase in height was noted in the settled solids layer.

This work shows that at dilution levels of $0.75: 1$ or greater using $2 \mathrm{M} \mathrm{NaOH}$, hazardous-gasrelease-event behavior is mitigated in Tank SY-103 waste. The 0.75:1 and 1.0:1 diluted samples experienced initial slurry growth as the vacuum was applied; however, the growth was quickly slowed by the release of gas from the solids in the form of large bubbles, up to $5 \mathrm{~mm}$ in diameter. Although slurry growth was not observed at the 3.0:1 dilution level, bubbles were seen releasing from the solids. The release of bubbles prevented the sludge from reaching neutral buoyancy and causing a rollover in the sample vessels. This behavior in Tank SY-103 would result in a continuous release of flammable gas to the dome space, but sudden releases causing conditions approaching a flammable atmosphere would be eliminated. 



\subsection{References}

Allemann, R.T., T.M. Burke, D.A. Reynolds, and D.E. Simpson. 1993. Assessment of Gas Accumulation and Retention-Tank 241-SY-101. WHC-EP-0576, Westinghouse Hanford Company, Richland, Washington.

Babad, H., J.L. Deichman, B.M. Johnson, D.K. Lemon, and D.M. Strachan. 1992. Mitigation/Remediation Concepts for Hanford Site Flammable Gas Generating Waste Tanks. WHCEP-0516, Westinghouse Hanford Company, Richland, Washington.

Babad, H., G.D. Johnson, J.A. Lechelt, D.A. Reynolds, L.A. Pederson, D.M. Strachan, D. Meisel, C.D. Jonah and E.C. Ashby. 1991. Evaluation of the Generation and Release of Flammable Gases in Tank 241-SY-101. WHC-EP-0517, Westinghouse Hanford Company, Richland, Washington.

Bredt, P.R., S.M. Tingey, and E.H. Shade. 1995. The Effect of Dilution on the Gas-Retention Behavior of Tank 241-SY-101 Waste. PNL-10781, Pacific Northwest Laboratory, Richland, Washington.

Fox, G.L., D.D. Stepnewski and R.P. Anantatmula. 1993. Tank 241-SY-103 Hazard Assessment. WHC-SD-WM-SAR-061, Westinghouse Hanford Company, Richland, Washington.

Gauglitz, P.A., and S.D. Rassat. 1995. Experimental Methods To Generate Retained Bubbles in Simulated Sludges. WTSFG95.10, Pacific Northwest Laboratory, Richland, Washington.

Gauglitz, P.A., S.D. Rassat, M.R. Powell, R.R. Shah, and L.A. Mahoney. 1995. Gas Bubble Retention and Its Effects on Waste Properties: Retention Mechanisms, Viscosity, and Tensile and Shear Strengths. PNL-10740, Pacific Northwest Laboratory, Richland, Washington.

Glasrud, G.G., R.C. Navarrete, L.E. Sciven, and C.W. Macosko. 1993. "Settling Behaviors of Iron Oxide Suspensions," AlChE Journal, 39(4), 560.

Hanlon, B.M. 1995. Waste Tank Summary Report for Month Ending July 31, 1995. WHC-EP-018288, Westinghouse Hanford Company, Richland, Washington.

Hansen, D.R., S.G. Metcalf, and K.W. Johnson. 1995. Tank Characterization Report for Double-Shell Tank 241-SY-103. WHC-SD-DP-074, Westinghouse Hanford Company, Richland, Washington.

Hudson, J.D., G.S. Barney, P.R. Bredt, A.R. Felmy, D.L. Herting, A.P. Larrick, D.A. Reynolds, C.W. Stewart, J.M. Tingey, and D.S. Trent. 1995. An Assessment of the Dilution Required to Mitigate Hanford Tank 241-SY-101. PNL-10417, Pacific Northwest Laboratory, Richland, Washington.

Norton, J.D., and L.R. Pederson. 1994. Ammonia in Simulated Hanford Double-Shell Tank Wastes: Solubility and Effects on Surface Tension. PNL-10173; Pacific Northwest Laboratory, Richland, Washington.

Stewart, C.W., L.A. Schienbein, J.D. Hudson, E.J. Eschbach, and D.L. Lessor. 1994. Assessment of Alternate Mitigation Concepts for Hanford Flammable Gas Tanks. PNL-10105, Pacific Northwest Laboratory, Richland, Washington.

Stewart, C.W., C.L. Shepard, J.M. Alzheimer, T.I. Stokes, G. Terrones, G. Chen, N.E. Wilkins. 1995. In Situ Determination of Rheological Properties and Void Fraction in Hanford Waste Tanks 241-SY103. PNL-10865, Pacific Northwest National Laboratory, Richland, Washington.

Tingey, J.M., P.R. Bredt, and E.H. Shade. 1994. The Effects of Heating and Dilution On the Rheological and Physical Properties of Tank 241-SY-101 Waste. PNL-10198, Pacific Northwest Laboratory, Richland, Washington.

Wilkins, N.E. 1995. Tank 241-SY-103 Core Sample: Interpretation of Results. WHC-SD-WM-TI-712, Westinghouse Hanford Company, Richland, Washington. 


\section{Distribution}

No. of

Copies

\section{OFFSITE}

2 DOE Office of Scientific and Technical Information

K. Pasamehmetoglu

TSA-6, MS K557

Los Alamos National Laboratory

Los Alamos, New Mexico 87545

\section{ONSITE}

3 DOE Richland Operations Office

J.M. Gray

C.A. Groendyke

G.W. Rosenwald

19 Westinghouse Hanford Company

H. Babad

G.S. Bamey

W.B. Barton

T.R. Benegas

C.E. Hanson

D.L. Herting

J.R. Jewett

G.D. Johnson

J.W. Lentsch

E.J. Lipke

N.G. McDuffie

J.C. Person

C.A. Reick

D.A. Reynolds

E.R. Siciliano

J.E. Van Beek

R.J. Van Vleet

J.R. White (LANL staff currently at WHC)

N.E. Wilkins
No. of

Copies

ONSITE

27 Pacific Northwest National Laboratory

J.M. Bates

P.R. Bredt (10)

J.W. Brothers

S.A. Bryan

P.A. Gauglitz

R.T. Hallen

J.D. Hudson

F.E. Panisko

S.D. Rassat

A. Shekarriz

C.W. Stewart

J.M. Tingey

S.M. Tingey

Technical Report File (5)

Dist. 1 